\title{
Vaginal Squamous Cell Carcinoma, Not Otherwise Specified
}

National Cancer Institute

\section{Source}

National Cancer Institute. Vaginal Squamous Cell Carcinoma, Not Otherwise Specified. NCI Thesaurus. Code C7736.

A squamous cell carcinoma arising from the vagina. Human papillomavirus infection is associated with the development of vaginal intraepithelial neoplasia and invasive squamous cell carcinoma. Signs and symptoms include painless bleeding, postcoital bleeding, and urinary tract symptoms. Morphologically it resembles squamous cell carcinomas in other anatomic sites. Radiation therapy is the preferred treatment for most cases. The prognosis is related to the stage of the disease. 